\title{
The Escherichia coli uropathogenic-specific-protein- associated immunity protein 3 (Imu3) has nucleic acid -binding activity
}

\author{
Miha Črnigoj, Zdravko Podlesek, Maruška Budič and Darja Žgur-Bertok
}

\begin{abstract}
Background: The Escherichia coli uropathogenic-specific protein (Usp) is a bacteriocin-like genotoxin, active against mammalian cells and associated with E. coli strains that provoke pyelonephritis, prostatitis and bacteraemia. Usp is encoded by a small pathogenicity island with three downstream small open reading frames (Imu1-3) that are believed to provide immunity to the producer. To prevent host suicide, colicins, bacteriocins of $E$. coli, form tight complexes with their cognate immunity proteins. Colicin - immunity protein complexes are among the strongest protein complexes known. Here, the Usp associated immunity protein 3 (Imu3) was partially characterized to gain insight into its role and mechanism of activity.

Results: Isolation and partial characterisation of the Usp-associated immunity protein-3 (Imu3) revealed that, while Usp and Imu3 do not form a high affinity complex, Imu3 exhibits DNA and RNA binding activity. Imu3 was also shown to protect DNA against degradation by colicin E7.

Conclusions: Our data infer that nonspecific DNA binding of the Imu3 immunity protein, prevents suicide of $E$. coli producing the genotoxin Usp.
\end{abstract}

Keywords: Escherichia coli, Imu3, Immunity protein, Uropathogenic-specific protein DNA/RNA binding

\section{Background}

The Escherichia coli uropathogenic-specific protein (Usp) has been shown to be associated with E. coli strains that provoke pyelonephritis, prostatitis and bacteraemia, and with increased virulence and fitness of pathogenic strains of $E$. coli [1-4]. Nucleotide sequence analysis has shown approximately $45 \%$ sequence identity of the Usp C-terminal region with that of the $E$. coli bacteriocin colicin E7, which has nuclease activity, while the Usp N-terminal region is similar to the Type VI protein secretion system component (Hcp like) [5-7]. It has been proposed that Usp acts as a bacteriocin against competing E. coli strains and that it also enhances infectivity in the urinary tract. Recently, we demonstrated the genotoxic activity of Usp against mammalian cells [5,8]. To protect the colicin-producing cell from its own toxin, colicin-encoding operons generally harbour one cognate

\footnotetext{
* Correspondence: darja.zgur.bertok@bf.uni-lj.si

Department of Biology, Biotechnical Faculty, University of Ljubljana, Ljubljana, Slovenia
}

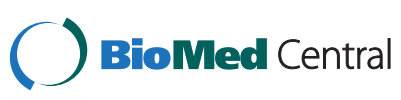

(C) 2014 Črnigoj et al.; licensee BioMed Central Ltd. This is an Open Access article distributed under the terms of the Creative Commons Attribution License (http://creativecommons.org/licenses/by/2.0), which permits unrestricted use, distribution, and reproduction in any medium, provided the original work is properly credited. The Creative Commons Public Domain Dedication waiver (http://creativecommons.org/publicdomain/zero/1.0/) applies to the data made available in this article unless otherwise stated. immunity gene [9]. Colicins and their immunity proteins have some of the strongest protein-protein affinities, which result in the formation of stable colicin-immunity protein complexes $[10,11]$. In contrast, downstream of the usp gene, there are three short open reading frames designated orfU1-3 (288, 294, and 291 bp long, respectively), that are believed to be involved in the protection of the Usp-producing cell from its own nuclease activity [5]. The immunity proteins coded by the usp gene operon have a characteristic two-histidine region which appears to enable the inactivation of the Usp DNase activity [10]. However, Usp-encoding strains that do not have all three orf $U$ immunity protein genes have been described. All three immunity proteins are thus not essential for the protection of the Usp producers, although Usp is lethal when it is expressed alone in E. coli. It has been postulated that none of the three proteins is exclusively required for Usp protein synthesis [6]. As protection of the Usp-producing bacterial cell might be provided by a mechanism that is different from that of the colicins, we have investigated the $E$. coli Usp-associated immunity protein Imu3, previously

res 
designated OrfU3. Our study indicates that Imu3 has protective non specific DNA-binding abilities that could have possible biotechnological potential.

\section{Results and discussion}

Isolation of Immunity protein 3 (Imu3) with Ni-NTA affinity chromatography provided protein fractions with appropriate purity; (Figure 1A). DNA binding ability was not affected by the presence or absence of the his-tag, as both precipitated linear DNA (Additional file 1: Figure S1). The theoretical and actual mass $(11.497 \mathrm{kDa})$ of the purified Imu3 differed by $1.5 \mathrm{Da}$ (measured by ESI + and Q-Tof; Waters-Micromass, United Kingdom, data not shown), indicating that Imu3 is not post-translationally modified. Parret and DeMot [5] previously described an approximately $45 \%$ sequence identity of the C-terminal region of the Usp protein with known nuclease colicins, such as colicins E7 and E9. Although it has been shown that colicin E7 and its immunity protein form a highaffinity complex [11], we were not able to confirm the formation of a high affinity complex between Usp and any of the three smaller proteins encoded downstream of the usp gene (data not shown) which were previously proposed to protect the Usp-producing cell against its endonucleolytic activity [5]. Nevertheless, our results showed that Imu3 protects isolated DNA from digestion by the nuclease colicin E7, indicating a nonspecific protection mechanism that is distinct from that of the colicin immunity proteins (Figure 2).

Induction of the cloned usp gene (without the immunity protein genes) was either lethal (liquid media) or resulted in severely diminished growth (plates). Of the three potential immunity proteins, when cloned separately downstream of the usp gene, Imu3 showed the greatest degree of protection as the number of transformants obtained was repeatedly higher, with larger colonies than for the other two (Figure 3, Table 1). We therefore focused our further investigation on Imu3.

\section{Imu3 dimerisation and USP binding}

Imu3 has fairly high sequence similarity to the colicin E7 immunity protein Cei, approximately $66 \%$ sequence identity as established with the MEGA program package, which was previously reported to form monomers [12]. We investigated potential dimer formation by Imu3, using the cross-linking glutaraldehyde assay, native PAGE electrophoresis and size exclusion chromatography (HPLC). Native PAGE as well as HPLC experiments clearly showed that, Imu3 does not form dimers or multimers since a single peak of size between 11 and $13 \mathrm{kDa}$ was observed regardless of the presence or absence of DNA

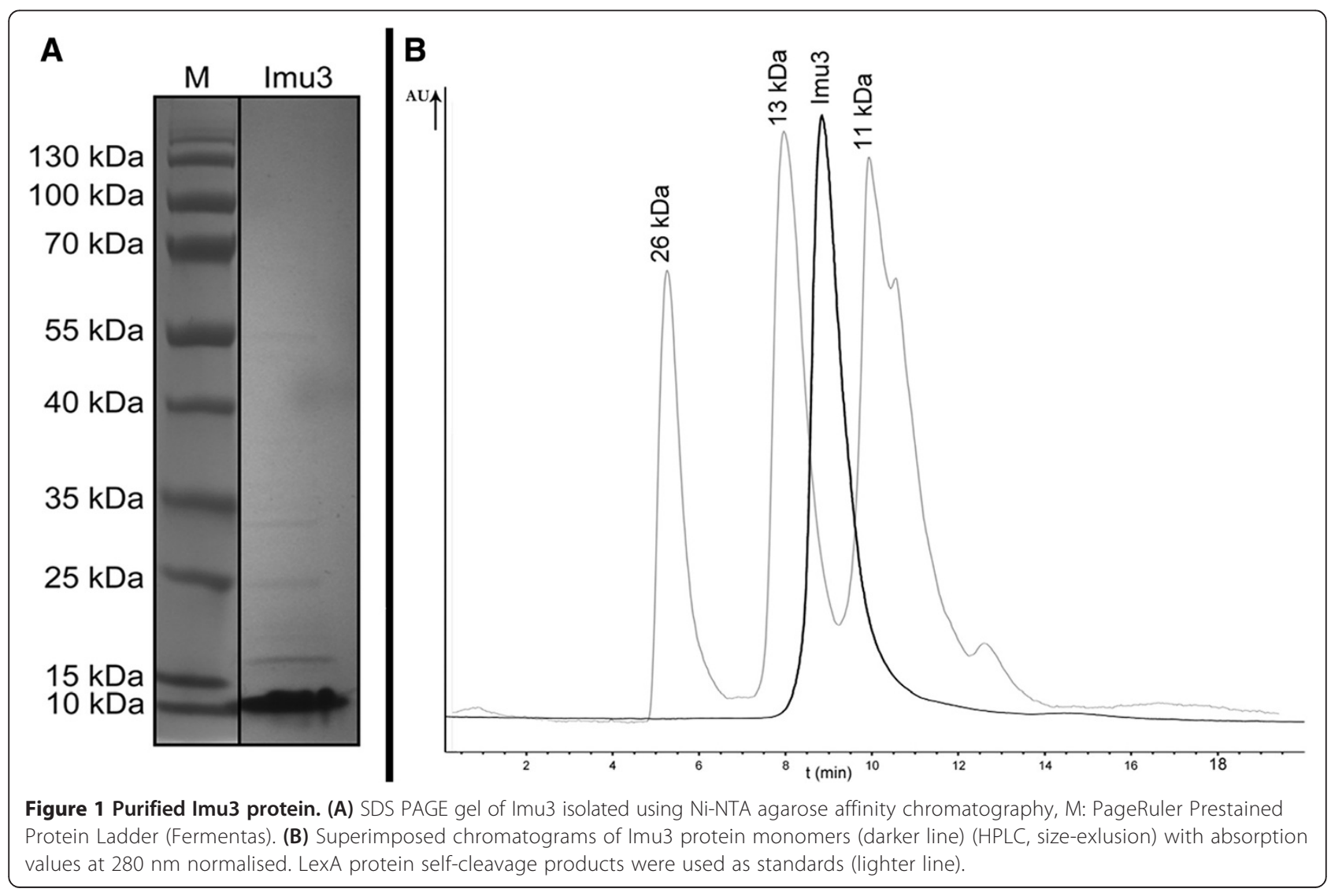




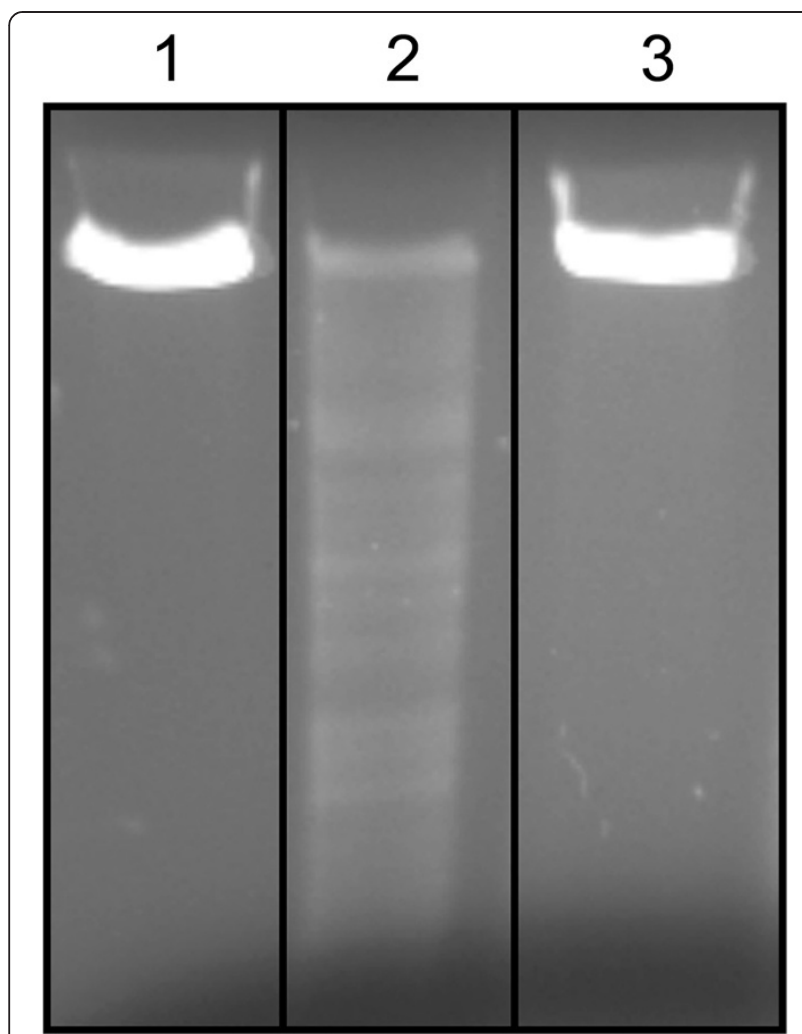

Figure 2 Imu3 protection against colicin E7 DNase activity. Lane $\mathbf{1}$ shows linear dsDNA, lane $\mathbf{2}$ colicin E7 with linear dsDNA, and lane $\mathbf{3}$ linear DNA with colicin E7 activity and Imu3.
(Figure 1B). Cross-linking studies of equimolar mixtures of Imu3 and Usp also showed no complex formation (Additional file 2: Figure S2).

\section{DNA/RNA binding}

Our data thus indicate that the Usp-producing cell is protected from the DNase activity of its own Usp by a mechanism that is distinct from that of colicin-producing cells. Surprisingly, EMSA showed that Imu3 binds linear and circular (Figure 4B) DNA as well as RNA molecules. When Imu3 reached a critical concentration (ca. $1 \mu \mathrm{g}$ Imu3 per 100 ng double-stranded linear or circular DNA), it repeatedly precipitated the DNA, which resulted in total retardation/precipitation of DNA in the electrophoresis (Figure 4A). When Imu3 was subjected to treatment with increasing concentrations of ions $\left(\mathrm{NaCl}\right.$ or $\left.\mathrm{Mg}^{2+}\right)$, the effects of DNA retardation were decreased (Figure 4A and C). Incubations at higher temperatures $\left(70-100^{\circ} \mathrm{C}\right)$ also reduced the gel shift effects of Imu3 on DNA (Figure 4B). The EMSA studies with DNA or E. coli total RNA clearly showed that Imu3 has DNA-binding as well as RNAbinding abilities. No such activity was observed with Imu1 or Imu2 (data not shown).

Furthermore, thermal denaturation curves $\left(\mathrm{A}_{260}\right)$ showed a stabilising effect of Imu3 on the linear double-stranded DNA molecule. The melting temperature (determined graphically) of DNA alone was $73^{\circ} \mathrm{C}$, which increased by $3^{\circ} \mathrm{C}\left(\mathrm{T}_{\mathrm{m}}=76^{\circ} \mathrm{C}\right)$ when an aliquot of $0.3 \mu \mathrm{g}$ Imu3 was added in the EMSA studies. The DNA melting temperature was further raised by an additional $13^{\circ} \mathrm{C}\left(\mathrm{T}_{\mathrm{m}}=89^{\circ} \mathrm{C}\right)$ when a $1 \mu \mathrm{g}$ aliquot of Imu3 was added. This concentration of Imu3 saturated the DNA, and the melting curve revealed a two-phase thermal transition. One transition showed a

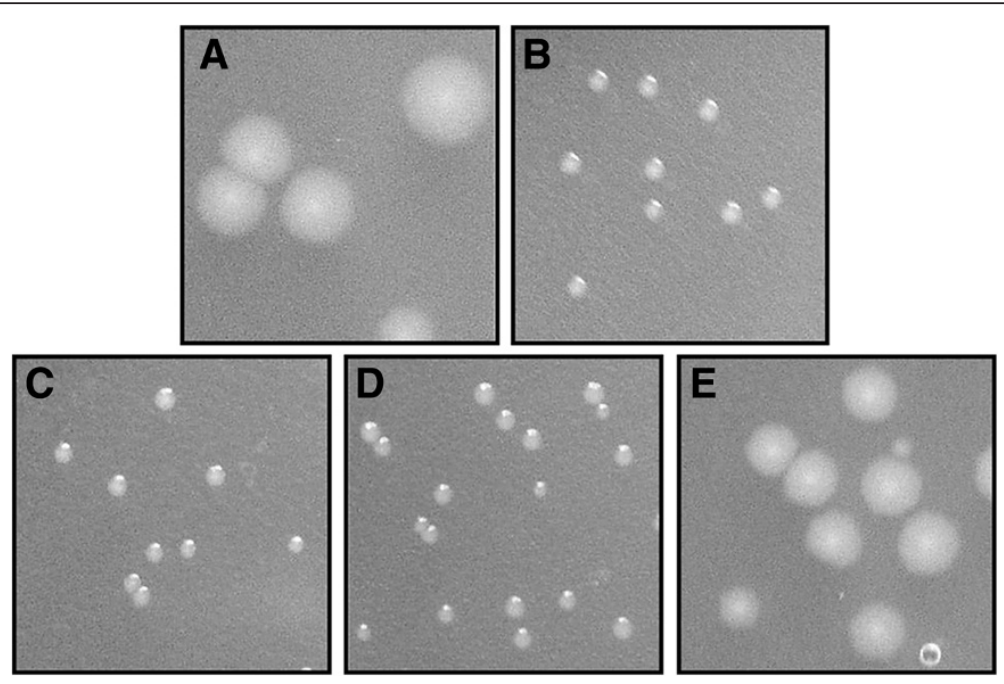

Figure 3 Protection of E. coli Usp producing cells by Imu proteins. Colonies encoding: A) usp imu1, imu2 and imu3, B) only usp C) usp imu1, D) usp imu2, and E) usp imu3 gene. The concentrations of the plated transformation mixtures were adjusted to obtain a comparable number of transformants for each strain. 
Table 1 Protection of Usp producing $E$. coli by the individual Imu proteins

\begin{tabular}{|c|c|}
\hline Strain & $\begin{array}{l}\% \text { of transformants relative } \\
\text { to control }\left(u s p^{+} \text {imu1-3) }\right.\end{array}$ \\
\hline$\overline{u s p^{+}}$ & $1.7 \pm 1.2$ \\
\hline$u s p^{+} i m u 1$ & $2.4 \pm 1.2$ \\
\hline usp $p^{+} i m u 2$ & $4.1 \pm 2.0$ \\
\hline usp $p^{+} i m u 3$ & $10.6 \pm 4.0$ \\
\hline
\end{tabular}

Relative numbers of transformants obtained with plasmids carrying the usp gene without and with the individual imu genes.

stabilisation effect $\left(89^{\circ} \mathrm{C}\right)$, whereas the other transition (at $63^{\circ} \mathrm{C}$ ) was shown to be destabilising (in terms of thermal stability), most probably due to partial DNA precipitation (Figure 5).

\section{Minimal DNA length for Imu3 binding}

Binding of short DNA fragments to Imu3 occupied all its free DNA binding sites, and therefore prevented subsequent binding of Imu3 to indicator DNA (EcoRI linearised pUC19). These EMSA tests showed that free Imu3 starts to bind to oligonucleotides longer than 11 base pairs, observed as the reappearance of unbound indicator DNA (absence of precipitation). These results indicate that 11 base pairs is the minimal DNA length required for Imu3 binding (Figure 6).

EMSA tests with short double stranded DNA fragments (re-annealed oligonucleotides) were also performed however, the results were inconclusive since we repeatedly observed the recurring effect of unbound Imu3 that re-/dis-appeared every 3-5 nucleotides of the oligonucleotide length; however, the underlying basis of this phenomena is unclear.

\section{Separation of Imu3 from DNA and subsequent DNA integrity analysis}

Separation of the DNA-Imu3 complex, was examined under different conditions. Exposure of the DNA-Imu3 complex to $\mathrm{pH}$ values between $\mathrm{pH} 3$ and $\mathrm{pH} 13$ showed separation at values between $\mathrm{pH} 11$ and $\mathrm{pH}$ 12. However, at $\mathrm{pH}$ values higher than $\mathrm{pH} 12.5$, DNA degradation was also observed. When the DNA-Imu3 complex was heated to $100^{\circ} \mathrm{C}$ for $5 \mathrm{~min}$ in the presence of
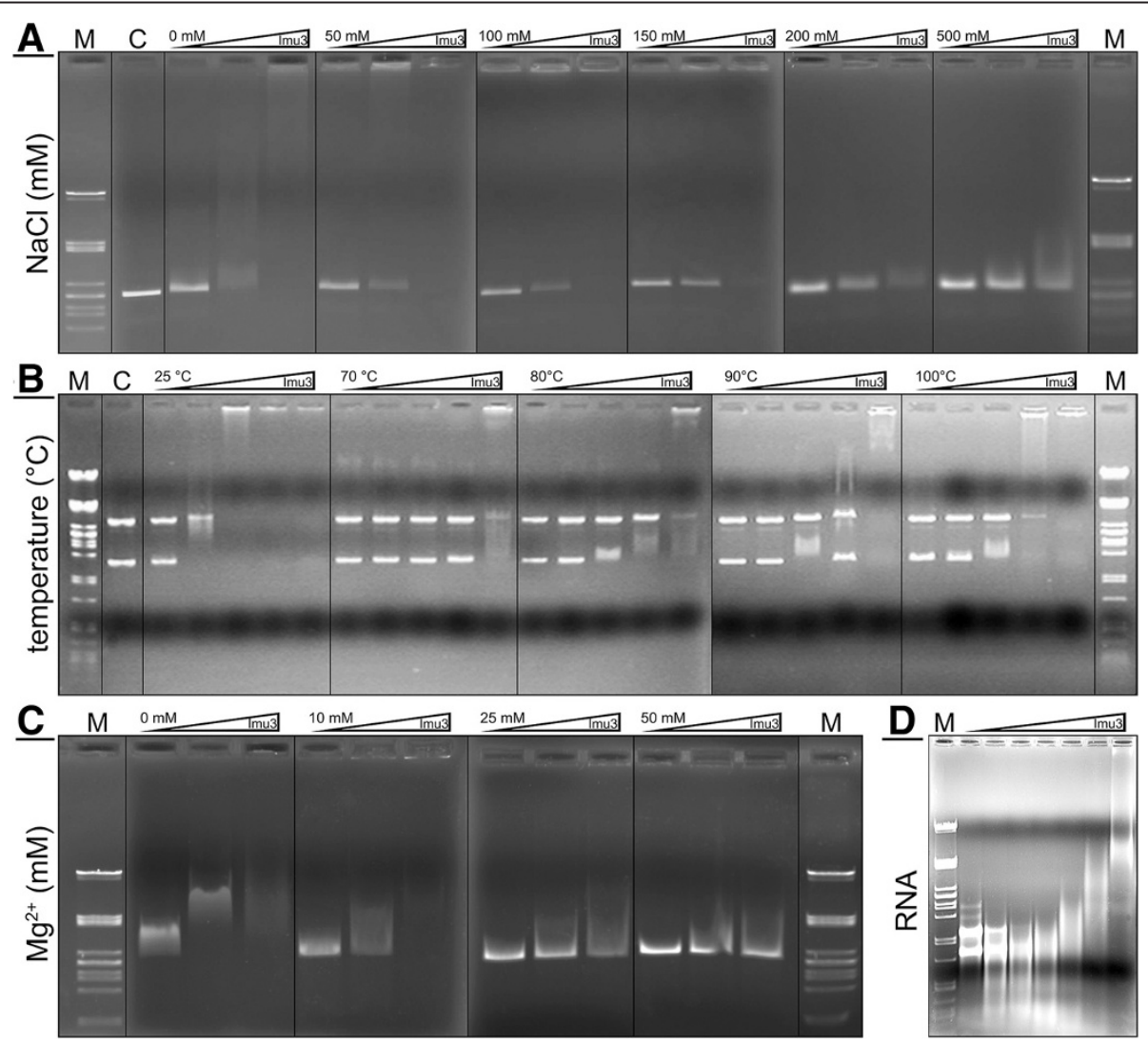

Figure 4 Representative electromobility shift assays on $\mathbf{0 . 8 \%}$ agarose gels. Effects of Imu3 binding to DNA ("a" and " $c$ " with pUC19/EcoRl, "b" with pUC19 and "d" RNA). (A) DNA: effect of NaCl (0 to $500 \mathrm{mM}$ ), Imu3 concentrations 0.3, 0.6 and 1.2 $\mu \mathrm{g}$. (B) DNA: effect of temperature (10-min incubation), Imu3 additions 0.0625 to $1.0 \mu \mathrm{g}$ (two fold increase/step). (C) DNA: effect of $\mathrm{Mg}^{2+}$ ions, Imu3 concentrations $0.3,0.6 \mathrm{and} 1.2 \mu \mathrm{g}$. (D) RNA: Imu3 additions 0.312 to $10 \mu \mathrm{g}$ (two fold concentration increase/step). (A, B, C, D) M: NPstl DNA marker; C: control (pUC19/EcoRl alone). 


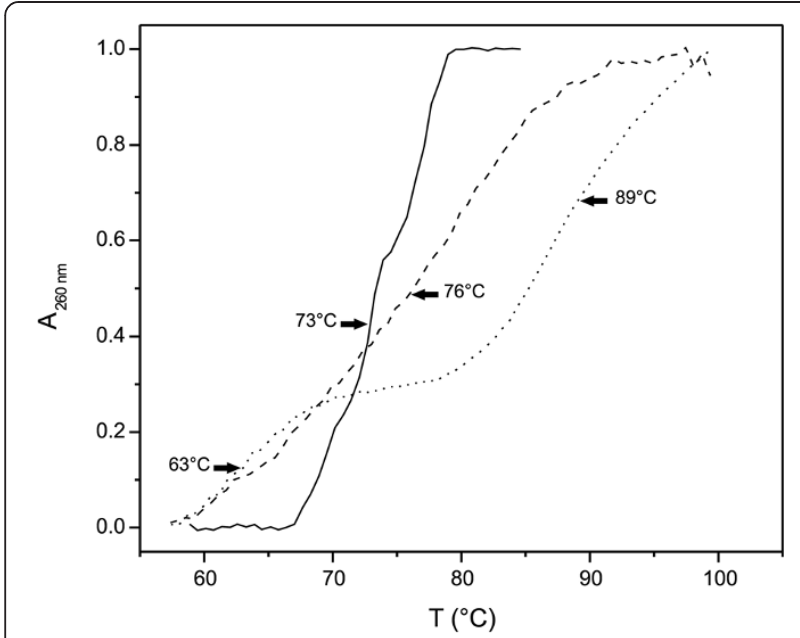

Figure 5 Thermal denaturation curves of $100 \mathrm{ng}$ pUC19/ECoRI DNA. DNA alone (solid line); DNA with Imu3 at $0.3 \mu \mathrm{g}$ (dashed line) and $1.0 \mu \mathrm{g}$ (dotted line). Signal of Imu3 alone was subtracted where necessary, and all curves were normalised. The arrows indicate the Tm values.

different $\mathrm{NaCl}$ concentrations, separation of Imu3 from DNA was observed at $0.5 \mathrm{M} \mathrm{NaCl}$ or higher (Additional file 3: Figure S3). Incubation of Imu3-DNA complexes with proteinase $\mathrm{K}$ resulted in unbound DNA due to degradation of Imu3.

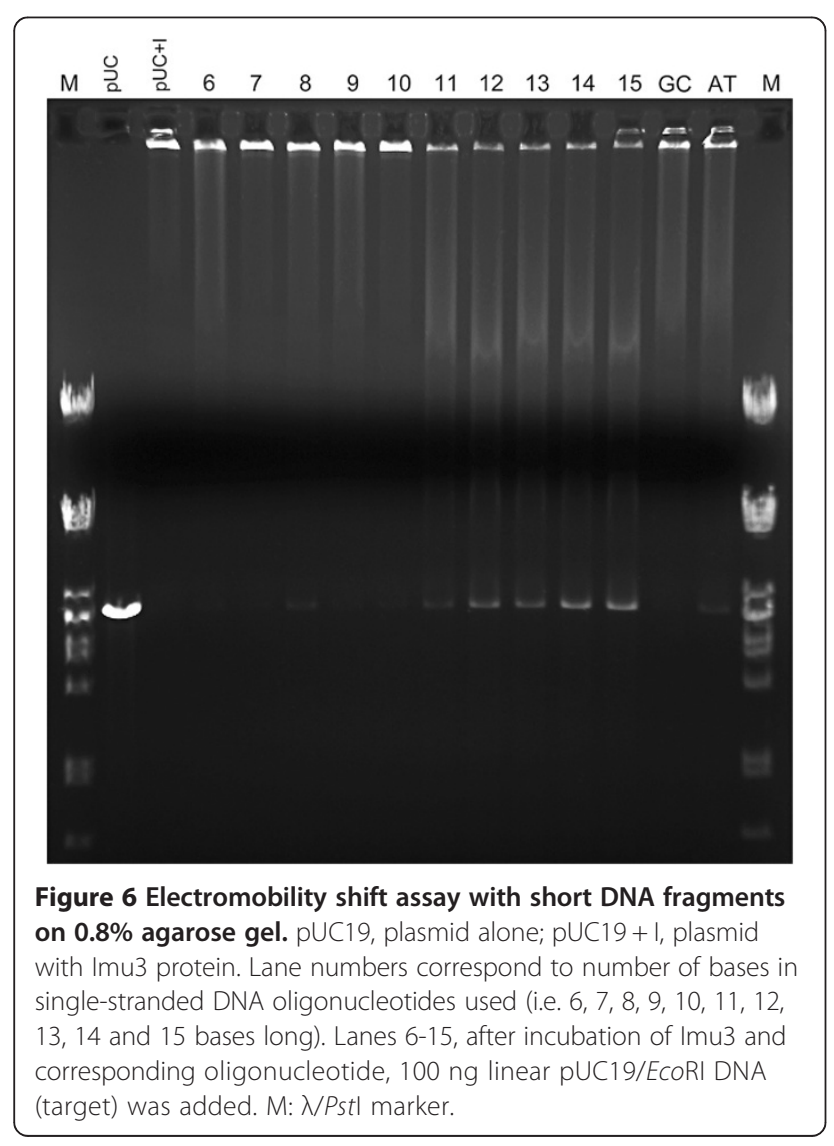

To determine whether DNA exposed to Imu3 could subsequently be used for molecular biological manipulations, linear plasmid pBR322 DNA that had been previously complexed with Imu3 was purified with the QIAgen commercial kit. This DNA could be re-ligated, transformed into E. coli, and again subjected to restriction enzyme activity. The integrity of precipitated and religated plasmid DNA was confirmed on the basis of expression of the ampicillin resistance gene among 500 analysed transformants (described in Methods). All procedures were also performed with DNA that had not been previously complexed as a control, and no apparent losses in quantity or quality of DNA were observed (with exception of losses originating from the DNA purification procedure) (Figure 7). Further, we found that Imu3 precipitated DNA from highly $\left(1.5 \times 10^{-4}\right.$ fold) diluted solutions, where $1 \mu \mathrm{L}$ (100 ng) of linear plasmid DNA was diluted in $15 \mathrm{~mL}$. This procedure yielded less DNA as the control but could without doubt be optimised with appropriate protocol modification (Additional file 4). The colicin DNases and their cognate immunity proteins are known to form high affinity complexes with the DNase domain $[11,12]$. In the present study, despite its two preserved histidines, as nuclease inactivation motifs that are present throughout the DNase immunity protein family, Imu3 showed no coupling with the USP protein, and Imu3 alone was shown to be sufficient for protection of Usp-producing cells. Not unexpectedly due to the sequence similarity of Imu3 with the colicin E7 immunity protein, which was shown by Dennis et al. [12] to be monomeric, we demonstrated, on the basis of different experiments that Imu3 does not undergo dimerisation or multimerisation.

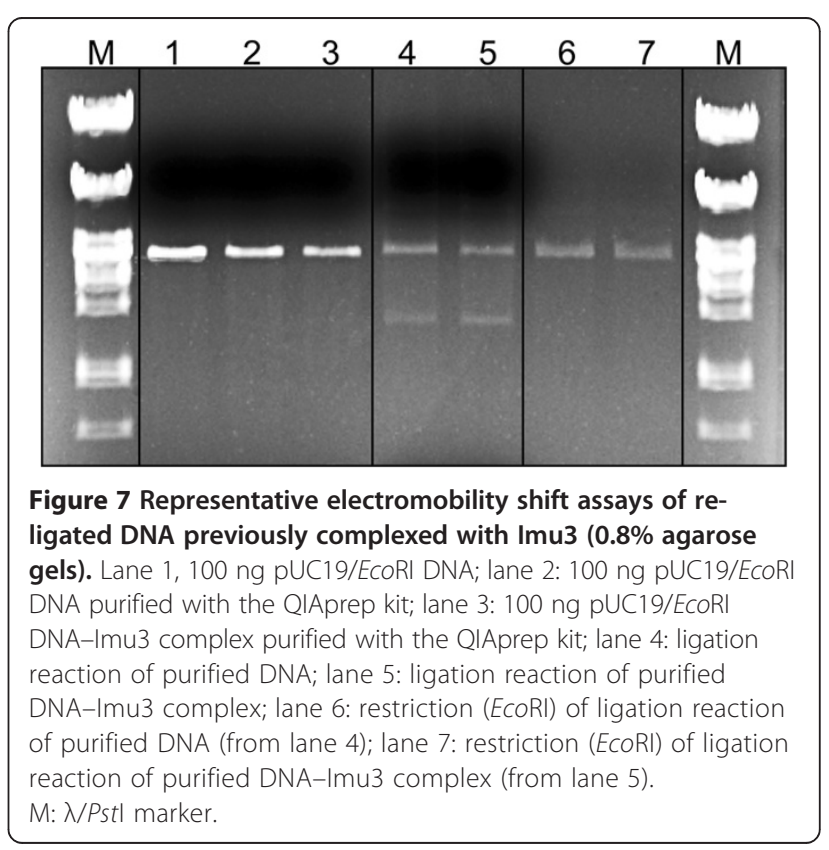


To the best of our knowledge, no known functions have been described yet for the protein products of orfU1, orfU2 and orfU3 (here referred to as Imu1, Imu2 and Imu3). Although all three immunity proteins of the Usp cluster share a high degree of sequence similarity, the present study shows that Imu3 has a distinct RNAand DNA-binding ability. Nevertheless, additional as of yet unresolved mechanisms could be involved in protection of Usp producing cells by its cognate immunity proteins. Interestingly, protein-mediated DNA precipitation has been reported in studies describing eukaryotic histones and the E. coli global regulator, protein $\mathrm{HU}$, a known DNA-binding protein $[13,14]$. Operons, such as those of colicins, that encode proteins that can be detrimental to the producing cell are regulated precisely to ensure appropriate timing of synthesis and avoid untimely death of the producer [15-17]. We can thus speculate that synthesis of Usp and its associated Imu1-3 proteins could also be tightly regulated, limiting their production to avoid overt degradation and masking of the producers' genome. Indeed high expression levels of imu3 (IPTG induced for protein isolation) are toxic for producing cells. DNAbinding (basic) proteins usually have an overall positive charge that facilitates their binding to DNA. The Imu3 protein, has a theoretical isoelectric point of $c a$. 4.4, which implies that the DNA-binding region must be localised only on part of the tertiary structure of the molecule. Different online DNA-binding motif search tools were used to identify a potential Imu3 DNA binding motif $[18,19]$. The results imply that the DNA-binding ability of Imu3 probably originates from the helix-turn-helix motif.

\section{Conclusions}

In conclusion, our study shows that Imu3 like the colicin E7 immunity protein Cei, does not form dimers and in addition, does not form a tight complex with the Usp protein. However, in contrast to the two other small proteins of the Usp pathogenicity island, Imu1 and 2, Imu3 does bind DNA and RNA. We propose that Usp producing cells are protected from genome fragmentation by Imu3 DNA masking. Further, as Imu3 precipitates but does not damage DNA we believe that could have biotechnological potential.

\section{Methods}

\section{Plasmid construction and protein expression}

The nucleotide sequences that encode Imu3 (USP-associated immunity protein 3 from $E$. coli) were amplified from the genomic DNA of the uropathogenic E. coli strain TA211 using standard PCR reactions. The Imu3n-F 5'-T TTCTCGAGCTATAATTTTAAAGATGAAATAG-3' and Imu3n.R 5'-TTTACGCGTTATTTAGAGTCTTTAAACA AG-3' primers were used, with $\mathrm{XhoI}$ and $\mathrm{MluI}$ restriction sites, respectively (in italics). The PCR product was cloned into the blunted pJET1.2 plasmid (Fermentas), and Usp-coding sequences were subsequently excised and re-cloned into the $X h o \mathrm{I}$ and $M l u \mathrm{I}$ sites of the pET8c expression plasmid, with an $\mathrm{N}$-terminal His tag (Novagen). Subsequently, Imu3 was expressed in the E. coli strain BL21(DE3) pLysE as described by the manufacturer (QIAgen). Briefly, an overnight culture of E. coli BL21(DE3) pLysE was diluted in liquid Luria Bertani medium supplemented with $120 \mathrm{mg} / \mathrm{L}$ ampicillin (LBAp medium) to an $\mathrm{OD}_{600}$ of 0.05 at $37^{\circ} \mathrm{C}$, and grown to an $\mathrm{OD}_{600}$ of 0.6. Imu3 production was induced by the addition of isopropyl $\beta$-D-1-thiogalactopyranoside (IPTG) to $0.8 \mathrm{mM}$ final concentration. The culture was grown for an additional $4 \mathrm{~h}$, and then the biomass was collected by 10 min centrifugation at $4,000 \times g$.

All of the isolation steps were carried out at $4^{\circ} \mathrm{C}$. The collected biomass was treated with DNase, RNase and lysozyme on ice for $1 \mathrm{~h}$, as described by the manufacturer (QIAgen), and complete EDTA-free protease inhibitor cocktail (Roche) was added. The cells were ruptured with 12 consecutive ultrasonication bursts (alternating $30 \mathrm{~s}$ pulse, $30 \mathrm{~s}$ pause) at the 55 setting (Sonics Vibra Cell). The cell lysates were cleared by three 20 min centrifugations at $20,000 \times \mathrm{g}$. All of the other protein isolation steps were carried out. When needed, Imu3 was further purified with size-exclusion FPLC chromatography (Superdex 75 HR 10/30, Amersham Biosciences) equilibrated with $50 \mathrm{mM}$ Tris- $\mathrm{HCl}, \mathrm{pH} 7.5$, containing $0.15 \mathrm{M} \mathrm{NaCl}$. Buffer exchanges were carried out using Amicon MWCO $3 \mathrm{kDa}$ microconcentrators (Millipore). The his-tag was removed with the Thrombin Cleavage Capture Kit (Novagen) as described by the manufacturer. Actual mass of Imu3 protein was determined via mass spectrometry ESI + and Q-Tof (Waters-Micromass, United Kingdom).

The degree of Usp-producing cell protection provided by each of the three individual immunity proteins (Imu1-3) was examined in E. coli BL21(DE3) pLysE cells that were transformed with the plasmid pET8c carrying the combination of Usp and either Imu1, Imu2 or Imu3. The transformants were isolated on LB Ap plates with IPTG ( $0.8 \mathrm{mM}$ final concentration) after being grown overnight at $37^{\circ} \mathrm{C}$.

\section{Imu3 and Usp binding}

Formation of a Imu3 dimer was checked using the cross-linking glutaraldehyde assay as previously described [20], native PAGE and size exclusion chromatography (HPLC).

Imu3 samples $(2 \mathrm{mg} / \mathrm{mL})$ with or without the addition of $2.7 \mathrm{kbp}$ double-stranded linear DNA (pUC19/EcoRI) were initially incubated at $37^{\circ} \mathrm{C}$ for $30 \mathrm{~min}$, to allow for potential multimerization. Samples were then subjected to either native PAGE resolution or to the glutaraldehyde 
cross-linking procedure and SDS-PAGE resolution, with the LexA protein as a dimerisation-positive control. Aditionally, Imu3 was checked for dimerisation with size exclusion chromatography (HPLC, Phenomenex Biosep SEC-S2000 column, flow rate: $1 \mathrm{~mL} / \mathrm{min}, 50 \mathrm{mM} \mathrm{NaH}{ }_{2} \mathrm{PO}_{4}$, $300 \mathrm{mM} \mathrm{NaCl}, \mathrm{pH} 8$ ), self-cleaved LexA protein was used as a standard (11 kDa, $13 \mathrm{kDa}$ and $26 \mathrm{kDa})$.

Formation of the Imu3-USP complex was also investigated using the glutaraldehyde assay, after Imu3 and Usp had been mixed in equimolar ratios.

\section{DNA/RNA binding}

Various concentrations of either EcoRI linearised pUC19 DNA or total RNA (isolated from E. coli) and the Imu3 protein were used to establish the nucleic-acid-binding ability of Imu3. The Imu3 was incubated with either the DNA or RNA in TE buffer (10 mM Tris, $1 \mathrm{mM}$ EDTA, $\mathrm{pH} 8)$ at $37^{\circ} \mathrm{C}$ for $30 \mathrm{~min}$, prior to the electromobility shift assays (EMSAs) with $0.8 \%$ agarose gels. The effects of temperature $\left(10 \mathrm{~min}\right.$ incubation at $70^{\circ} \mathrm{C}, 80^{\circ} \mathrm{C}, 90^{\circ} \mathrm{C}$ and $\left.100^{\circ} \mathrm{C}\right), \mathrm{pH}(6,7,8,9), \mathrm{NaCl}(0-500 \mathrm{mM})$ and $\mathrm{Mg}^{2+}$ ions concentrations $(0-50 \mathrm{mM})$ on the DNA binding ability of Imu3 were studied.

Thermal denaturation curves of linearised pUC19 DNA and the Imu3 protein were carried out in $5 \mathrm{mM}$ cacodylic buffer (pH 6.5) using a UV-vis spectrophotometer (Cary Varian Cary 100 Bio, Australia) equipped with a thermoelectrically controlled cell holder. UV absorption was measured as a function of temperature (UV melting curves) for different ratios of linear DNA and Imu3 (0, 0.3 and $1.0 \mu \mathrm{g}$ per $100 \mathrm{ng}$ DNA), at $260 \mathrm{~nm}$. The UV melting temperature ranged from $25^{\circ} \mathrm{C}$ to $99^{\circ} \mathrm{C}$, with a heating rate of $1^{\circ} \mathrm{C} \cdot \mathrm{min}^{-1}$ and an equilibration time of $1 \mathrm{~min}$. The melting curves of buffer and of the Imu3 protein alone were subtracted from the melting curves of the DNA-Imu3 protein complex, providing curves that show only the changes in the thermal stability of the DNA.

Further, the influences of $\mathrm{pH}$, temperature and ionic strength on the separation of the DNA-Imu3 complex were examined. The effects of $\mathrm{pH}$, were examined in the range from $\mathrm{pH} 3$ to $\mathrm{pH} 13$. Buffers used for these $\mathrm{pH}$

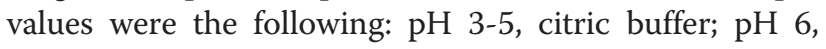
MES buffer; $\mathrm{pH}$ 7-9, TRIS buffer; $\mathrm{pH}$ 10-12, glycine/ $\mathrm{NaOH}$ buffer; $\mathrm{pH} 13, \mathrm{NaOH}$. The impacts of various ions on the separation of the DNA-Imu3 complex were studied as $0-1 \mathrm{M} \mathrm{NaCl}, 350 \mathrm{mM} \mathrm{KCl}, 350 \mathrm{mM} \mathrm{NaSCN}$, $70 \mathrm{mM} \mathrm{MgCl} 2,0.7 \%$ SDS, 1-3 $\mathrm{M}\left(\mathrm{NH}_{4}\right)_{2} \mathrm{SO}_{4}$ and $2.3 \mathrm{M}$ guanidinium thiocyanate. The effects of temperature were studied $80^{\circ} \mathrm{C}$ and $95^{\circ} \mathrm{C}$, with a 10 min incubation of the complex, and at $100^{\circ} \mathrm{C}$, with a $5 \mathrm{~min}$ incubation.

To examine whether Imu3 binding to DNA triggers any DNA damage, religation experiments were performed. Initially, the linear plasmid DNA (pUC19) was incubated with the Imu3 protein at $37^{\circ} \mathrm{C}$ for $30 \mathrm{~min}$, to allow for the DNA-Imu3 complex to form. The samples were subsequently purified using the QIAprep Spin Miniprep kits (QIAgen). To check DNA integrity, the linearised DNA was used for a (self) ligation reaction (Fermentas); half of the ligation mixture was transformed into E. coli $\mathrm{DH} 5 \alpha$, while the other half was subjected to a second restriction (EcoRI).

The structural integrity of the Imu3 precipitated plasmid DNA was also investigated on the basis of detection of potential mutations within a non-selected marker, the ampicillin resistance gene. For this purpose, plasmid pBR322 carrying both tetracycline and ampicillin resistance genes was employed. Plasmid DNA was digested with Pst $\mathrm{I}$, with a single restriction site within the ampicillin resistance gene to yield one linear DNA fragment. Following gel electrophoresis the linear plasmid DNA was precipitated with Imu3 and centrifuged for $10 \mathrm{mi}$ nutes at $4^{\circ} \mathrm{C}$, followed by washing with $0.5 \mathrm{ml}$ of TE buffer. The pellet was subsequently treated with the PCR Cleaning Kit (Thermo Scientific) and several $\mu \mathrm{l}$ of the isolate were employed for re-ligation. In control experiments, ligase was omitted. Transformants were isolated upon selection for tetracycline resistance. Five hundred transformants were further screened and all found to express ampicillin resistance.

\section{Minimum DNA length for Imu3 binding}

The minimum length of single-stranded DNA required for Imu3 binding was studied by initially saturating Imu3 with short DNA fragments of known lengths. The reaction mixtures of Imu3 $(10 \mu \mathrm{g})$ and an at least 5 -fold excess of oligonucleotides, were incubated for $30 \mathrm{~min}$ at $37^{\circ} \mathrm{C}$ (allowing Imu3 to bind to oligonucleotides of sufficient length) prior to the addition of the indicator DNA

Table 2 Oligonucleotide sequences used to determine the minimal length of single-stranded and double-stranded DNA for DNA-Imu3 complex formation

\begin{tabular}{llc}
\hline Oligonucleotide & $\mathbf{5}^{\prime}$-3' sequence & gCc \\
\hline 6-mer (M13) & gCggTTcv & 67 \\
7-mer (M13) & gCggTC & 63 \\
8-mer (M13) & TggCggT & 63 \\
9-mer (M13) & gTggCggT & 67 \\
10-mer (M13) & ggTggCggT & 70 \\
11-mer (M13) & ggTggCggTTC & 73 \\
12-mer (M13) & AgggTggCggTT & 67 \\
13-mer (M13) & gAgggTggCggTT & 69 \\
14-mer (M13) & gAgggTggCggTTC & 71 \\
15-mer (M13) & gAgggTggCggTCT & 67 \\
15-TATA (poly AT) & TATATATATATATAT & 0 \\
15-gCgC (poly GC) & gCgCgCgCgCgCgCg & 100 \\
\hline
\end{tabular}

The lengths of the oligonucleotides spanned from 6 to 32 nucleotides. 
(100 ng pUC19/EcoRI). Oligonucleotides too short to form a complex with Imu3, bind to the indicator DNA provoking an electro-mobility shift. Samples were incubated for another $30 \mathrm{~min}$ at $37^{\circ} \mathrm{C}$, to allow potential binding of Imu3 to the indicator DNA. The samples were later resolved on $0.8 \%$ agarose Tris-borate gels. The short DNA fragments were all synthesised as singlestranded oligonucleotides, the sequences of which are given in Table 2.

\section{Additional files}

Additional file 1: Figure S1. Effect of His-tag presence on Imu3 DNA-binding ability. M: PageRuler Prestained Protein Ladder (Fermentas); 1. Imu3 with His-tag (SDS-PAGE); 2. Imu3 with His-tag removed (SDS-PAGE); 3. $100 \mathrm{ng}$ of pUC19/EcoRI (agarose electrophoresis, AE); $4.100 \mathrm{ng}$ of pUC19/ EcoRl complexed with Imu3 with His-tag removed (AE).

Additional file 2: Figure S2. Dimerisation of Imu3 and USP proteins, 10\% SDS PAGE gel. M: PageRuler Prestained Protein Ladder (Fermentas); 1. Imu3 protein (11.5 kDa); 2. USP protein (67 kDa). Samples following cross-linking with glutaraldehyde (3-7); 3. Imu3 protein, 4. USP protein, 5. Imu3 and USP, 6. Imu3 and USP with addition of DNA, 7. LexA protein mono/dimer (24/48 kDa).

Additional file 3: Figure S3. Representative electromobility shift assays on $0.8 \%$ agarose gels. Effects of $\mathrm{pH}, \mathrm{NaCl}$ and temperature on DNA-Imu3 complex relaxation. Lane 1: pUC19/ECoRI DNA (100 ng); lane 2: Imu3-pUC19/ EcoRI untreated complex; lanes 3-7: Imu3-pUC19/EcoRI complex treated with $\mathrm{pH}$ values 10, 11, 12, 12.5, 13; lanes 8-11: Imu3-pUC19/EcoRI complex incubated $5 \mathrm{~min}$ at $100^{\circ} \mathrm{C}$ in the presence $0,0.2,0.5$ and $1 \mathrm{M} \mathrm{NaCl}$; lanes 12-14: complex treated with $0,0.5$ and $1 \mathrm{M} \mathrm{NaCl}$ at $\mathrm{pH} 12$

Additional file 4: Figure S4. DNA precipitation from diluted systems. On agarose gel: 1. pUC19/ECoRI (100 ng); 2. pUC19/ECoRI purified with GeneJet PCR purification Kit (Fermentas); 3. $100 \mathrm{ng}$ of pUC19/ECoRI diluted $1.5 \times 10^{-4}$ in $15 \mathrm{~mL}$ buffer and salvaged with Imu3 precipitation and subsequent GeneJet PCR purification Kit Imu3 removal.

\section{Competing interests}

The authors declare that they have no competing interests.

\section{Authors' contributions}

Conceived and designed the experiments: MČ ZP DŽB. Performed the experiments: MČ MB ZP. Contributed reagents/materials/analysis tools: DŽB. Wrote the paper: MČ DŽB. All authors read and approved the final manuscript.

\section{Acknowledgements}

This work was financed by the Slovene Research Agency (ARRS). We would like to thank Dušan Žigon for help with mass spectroscopy, Nataša Poklar Ulrih with DNA melting experiments and Luka Ausec for assistance with bioinformatics issues.

Received: 11 September 2013 Accepted: 20 January 2014 Published: 28 January 2014

\section{References}

1. Ostblom A, Adlerberth I, Wold AE, Nowrouzian FL: Pathogenicity island markers, virulence determinants malx and usp, and the capacity of Escherichia coli to persist in infants' commensal microbiotas. Appl Environ Microbiol 2011, 77(7):2303-2308.

2. Bauer RJ, Zhang LX, Foxman B, Siitonen A, Jantunen ME, Saxen H, Marrs CF: Molecular epidemiology of 3 putative virulence genes for Escherichia coli urinary tract infection - usp, iha, and iroN(E-coli). J Infect Dis 2002, 185(10):1521-1524.

3. Kanamaru S, Kurazono H, Ishitoya S, Terai A, Habuchi T, Nakano M, Ogawa O, Yamamoto S: Distribution and genetic association of putative uropathogenic virulence factors iroN, iha, kpsMT, ompT and usp in
Escherichia coli isolated from urinary tract infections in Japan. $J$ Urol 2003, 170(6):2490-2493.

4. Kurazono H, Yamamoto S, Nakano M, Nair GB, Terai A, Chaicumpa W, Hayashi $\mathrm{H}$ : Characterization of a putative virulence island in the chromosome of uropathogenic Escherichia coli possessing a gene encoding a uropathogenic-specific protein. Microb Pathog 2000, 28(3):183-189.

5. Parret AHA, De Mot R: Escherichia coli's uropathogenic-specific protein: a bacteriocin promoting infectivity? Microbiol-Sgm 2002, 148:1604-1606.

6. Nakano M, Yamamoto S, Terai A, Ogawa O, Makino S, Hayashi H, Nair GB, Kurazono $\mathrm{H}$ : Structural and sequence diversity of the pathogenicity island of uropathogenic Escherichia coli which encodes the USP protein. FEMS Microbiol Lett 2001, 205(1):71-76.

7. Papadakos G, Wojdyla JA, Kleanthous C: Nuclease colicins and their immunity proteins. Q Rev Biophys 2012, 45(1):57-103.

8. Nipič D, Podlesek Z, Črnigoj M, BudiČ M, Žgur-Bertok D: The Escherichia coli uropathogenic specific protein Usp, is a bacteriocin-like genotoxin. $J$ Infect Dis 2013. In press.

9. Cascales E, Buchanan SK, Duche D, Kleanthous C, Lloubes R, Postle K, Riley M, Slatin S, Cavard D: Colicin biology. Microbiol Mol Biol Rev 2007, 71(1):158-229.

10. Wallis R, Leung KY, Pommer AJ, Videler H, Moore GR, James R, Kleanthous C: Protein-protein interactions in colicin E9 DNase-immunity protein complexes .2. Cognate and noncognate interactions that span the millimolar to femtomolar affinity range. Biochemistry 1995, 34(42):13751-13759.

11. Ko TP, Liao CC, Ku WY, Chak KF, Yuan HS: The crystal structure of the DNase domain of colicin E7 in complex with its inhibitor Im7 protein. Struct Fold Des 1999, 7(1):91-102.

12. Dennis CA, Videler H, Pauptit RA, Wallis R, James R, Moore GR, Kleanthous C: A structural comparison of the colicin immunity proteins $\operatorname{Im} 7$ and $\operatorname{Im} 9$ gives new insights into the molecular determinants of immunity-protein specificity. Biochem J 1998, 333:183-191.

13. Guo FS, Adhya S: Spiral structure of Escherichia coli $\mathrm{HU}$ alpha beta provides foundation for DNA supercoiling. Proc Natl Acad Sci U S A 2007, 104(11):4309-4314

14. Vogel T, Singer MF: The effect of Superhelicity on the interaction of Histone f1 with closed circular duplex DNA. J Biol Chem 1976, 251(8):2334-2338.

15. Kuhar I, van Putten JPM, Zgur-Bertok D, Gaastra W, Jordi B: Codon-usage based regulation of colicin $\mathrm{K}$ synthesis by the stress alarmone ppGpp. Mol Microbiol 2001, 41(1):207-216.

16. Mulec J, Podlesek Z, Mrak P, Kopitar A, Ihan A, Zgur-Bertok D: A cka-gfp transcriptional fusion reveals that the colicin $\mathrm{K}$ activity gene is induced in only 3 percent of the population. J Bacteriol 2003, 185(2):654-659.

17. Butala M, Sonjak S, Kamensek S, Hodoscek M, Browning DF, Zgur-Bertok D, Busby SJW: Double locking of an Escherichia coli promoter by two repressors prevents premature colicin expression and cell lysis. Mol Microbiol 2012, 86(1):129-139.

18. Combet C, Blanchet C, Geourjon C, Deleage G: NPS@: network protein sequence analysis. Trends Biochem Sci 2000, 25(3):147-150.

19. Wang LJ, Brown SJ: BindN: a web-based tool for efficient prediction of DNA and RNA binding sites in amino acid sequences. Nucleic Acids Res 2006, 34:W243-W248.

20. Craig WS: Determination of quaternary structure of an active enzyme using chemical cross-linking with glutaraldehyde. Methods Enzymol 1988 156:333-345.

doi:10.1186/1471-2180-14-16

Cite this article as: Črnigoj et al:: The Escherichia coli uropathogenic-specificprotein-associated immunity protein 3 (Imu3) has nucleic acid -binding activity. BMC Microbiology 2014 14:16. 